\title{
女子大学生の緑黄色野菜摂取量と 高比重リポ蛋白コレステロールとの関係
}

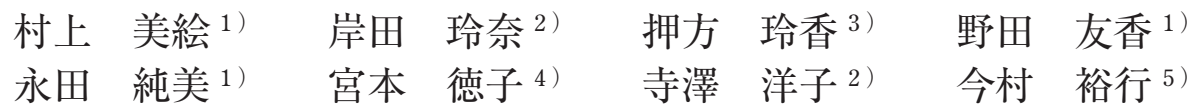

\begin{abstract}
要 旨 本研究の目的は, 緑黄色野菜の撕取量と高比重リポ蛋白コレステロール (HDL-C) との関 係について検討することである。被検者は，健康で契煙や飲酒習慣を有さない女子大学生 103 名であ る。重回帰分析を行ったところ, HDL-C と $\mathrm{HDL}_{2}-\mathrm{C}$ は緑黄色野菜の摂取量と体重にそれぞれ独立し た関係が認められた。緑黄色野菜を摂取量別に 3 群に分け，共分散分析にて体重の影響を除いたとこ ろ, 少ない群の HDL-C は, 中間群と多い群のそれぞれに比較して有意な低値を示した。本研究の結 果から, 健康な女子大学生に打いて緑黄色野菜摂取量は $\mathrm{HDL}-\mathrm{C}$ と $\mathrm{HDL}_{2}-\mathrm{C}$ とともに関連があり, 緑 黄色野菜摂取量が少ないと HDL-C の低下を招くことが示唆された。
\end{abstract}

キーワード：高比重リポ蛋白コレステロール，緑黄色野菜摂取量，生活習慣病，女子大学生

はじめに

野菜の摂取が，癌をはじめとする生活習慣病予防 に効果的であることは，これまでにも明らかにされ ている ${ }^{1,2)}$ 。野菜の摂取が七トの健康に寄与する因 子としては, 抗酸化力, 解毒酵素の修飾, 免疫力の 刺激，血小板凝集の低下，コレステロール代謝の変 化, ステロイドホルモン濃度とホルモン代謝の変化, 血圧の低下, 細菌・ウイルスへの抵抗などが報告さ れている3)。

本邦では，生活習慣病の一次予防を目的として， 2000 年に「健康日本 $21 」$ が制定され，日本人の野 菜摂取量の目標值が「成人 1 日 $350 \mathrm{~g}$ 以上，うち緑 黄色野菜 $120 \mathrm{~g}$ 以上」として具体的に示された ${ }^{4)}$ 。 しかし, 野菜が疾病予防に寄与しているといわれて いるにもかかわらず，60～69 歳男性の摂取量を除 いてはその目標値には達していない。特に若い世代 の摂取量は依然少ないのが現状である ${ }^{5)}$ 。

〔論文受付日：2009 年 6 月 29 日]

1 ) 中村学園大学大学院栄養科学研究科

2 ) 中村学園大学栄養科学部栄養科学科

3 ）精華女子短期大学生活科学科

4 ) 西九州大学健康福祉学部健康栄養学科

5 ) 長崎国際大学健康管理学部健康栄養学科
「動脈硬化性疾患予防ガイドライン 2007 年版」で は, 脂質異常症の診断基準值を設定し，高比重リポ 蛋白コレステロール（HDL-C） が $40 \mathrm{mg} / \mathrm{d} l$ 未満を 低 HDL-C 血症としている。低 HDL-C 血症が動脈 硬化症の危険因子であることは，すでに確立されて いる ${ }^{6)}$ 。また，虚血性心疾患で HDL-C が低いこと が示されている ${ }^{7)}$ 。HDL-C が低くなる原因として, 偏食, 肥満, 運動不足, 㖓煙などが挙げられてい る 8,9$)$ 。生活習慣病の改善に, 食事療法の意義は大 きい。飽和脂肪酸の制限や魚類の推奨，抗酸化成分 やコレステロール低下作用を持つ食物繊維を含む野 菜の摂取は，動脈硬化などの予防へ大きく寄与する と考えられている ${ }^{10)}$ 。

野菜の摂取量と血清脂質に関する報告には，若年 女性を対象とした報告があまり見られない3)。本研 究は, 健康な女子大学生を対象に, 緑黄色野菜の摂 取量と HDL-C の関係について検討することを目的 とした。

方法

対象は，健康で喫煙や飲酒習慣を有さない，月経 周期が正常な女子大学生 103 名である。本研究の実 施に当たっては，その趣旨と内容について十分説明 
した後に，被検者およびその保護者から同意書を回 収した。また、ヘルシンキ宣言の精神を遵守し, 中 村学園大学倫理委員会の承認を得た。

身長と体重は，それぞれ $0.1 \mathrm{~kg}$ と $0.1 \mathrm{~cm}$ まで測 定し，それらの值から body mass index (BMI ; $\left.\mathrm{kg} / \mathrm{m}^{2}\right)$ を算出した。

身体活動量については, クラブやサークルで習慣 的に行っている運動種目および通学手段と, それら の頻度と時間をアンケート用紙に記入させた。運動 強度は, Ainsworth らの報告 ${ }^{11,12)}$ に従って metabolic equivalents（METs）で表し，それに運動時間と一 週間の頻度を乗じ，METs・hour/week（METs • h/W）を算出した。

食事調查は秤量・目安法によって行った。被検者 に平日 3 日間の食事内容および重量を記録させ, や むを得ず計量できなかった場合は目安量を記録させ た。その後管理栄養士がフードモデルを用いて個人 面接を行い, 記録内容の確認と不備を補った。各栄 養素等摂取量は五訂増補日本食品標準成分表に準拠 した栄養計算ソフト・エクセル栄養君 Version4.5 (建 帛社, 東京) を用いて栄養素等摂取量と食品群別摂 取量について計算し, 更に残差法でエネルギー調整 を行い，分析に使用した。

血液検查は, 月経周期による女性ホルモンの変動 を考慮し，エストロゲンの影響をできるだけ同じ条 件にするため，月経開始より 6〜12 日目に採血を実 施した ${ }^{13)}$ 。前日は運動, 飲酒, 契煙, カフェイン の摂取を禁止した。採血は, 空調により $25^{\circ} \mathrm{C} に$ 保 たれた室内で, 10 時間以上の絶食状態で, 午前 8 時から 9 時の間に椅座位にて 20 分以上の安静後, 肘静脈より真空採血管を用いて約 $13 \mathrm{~m} l$ を採取し た。採取した血液は直ちに氷中に保存し, 血液成分 の分析を(株)SRLに依頼した。HDL-C と低比重り ポ蛋白コレステロール (LDL-C) は直接法, $\mathrm{HDL}_{2}{ }^{-}$ $\mathrm{C}$ と $\mathrm{HDL}_{3}-\mathrm{C}$ は超遠心法, アポリポ蛋白 (Apo) A-I とApo B は免疫比濁法, 中性脂肪 (TG) と総コレ ステロール（TC）は酵素法, レシチン-コレステロー ルアシルトランスフェラーゼ (LCAT) はデイパル ミトイル・レシチン基質法にて測定した。

統計処理は統計処理ソフト SPSS Version 10.0J （SPSS Inc., IL., USA）を用いて行った。3 群間の平 均值の差の検定は, 共分散分析を用いて, 体重の影 響を補正して行った。単相関は Pearson 検定, 重回 㫶分析はステップワイズ検定を用いて行った。有意 水準は $5 \%$ とした。結果は平均值 \pm 標準偏差あるい
は標準誤差で表した。

結＼cjkstart果

表 1 は被検者の身体的特徵および血液生化学検査 值を示したものである。BMI の平均值は $20.6 \pm 1.6$ $\mathrm{kg} / \mathrm{m}^{2}$ で, $25 \mathrm{~kg} / \mathrm{m}^{2}$ 以上の肥満者はいなかった。 身体活動量の平均は $18.7 \pm 12.3 \mathrm{METs} \cdot \mathrm{h} / \mathrm{W}$ であっ た。また, すべての被検者の血清脂質の值は(株) SRLの基準值内であった。

表 2 は, 被検者の栄養素等摂取量のうち, 特に野 菜の影響を受ける可能性のある項目および, 被検者 の食品群別摂取量のうち，血清脂質に影響を及ぼす 可能性のある項目を示したものである。被検者の野 菜摂取量は $168.1 \pm 113.8 \mathrm{~g}$ で, うち緑黄色野菜摂取 量は, $74.1 \pm 55.0 \mathrm{~g}$ であった。

表には示していないが, 食品群別摃取量と血清脂 質の単相関分析を行った結果, 緑黄色野菜の摂取量 と HDL-C $(r=0.246, p<0.05), \mathrm{HDL}_{2}-\mathrm{C}(r=0.279$, $p<0.01 ）$ との間に有意な正の関係が認められた。 また体重と HDL-C $(r=-0.220, p<0.05), \mathrm{HDL}_{2}-\mathrm{C}$ $(r=-0.212, p<0.05)$ との間に有意な負の関係が 認められた。しかしその他の野菜の摃取量,

$\mathrm{METs} \cdot \mathrm{h} / \mathrm{W}$ ，および年齢は HDL-C と $\mathrm{HDL}_{2} \mathrm{C}$ と 有意な相関を示さなかった。

表 1 身体的特徵および血液生化学検査值

\begin{tabular}{|c|c|}
\hline & \\
\hline 年齢（歳） & $21 \pm 1$ \\
\hline 身長（cm） & $159.7 \pm 4.9$ \\
\hline 体重（kg） & $52.7 \pm 5.1$ \\
\hline BMI $\left(\mathrm{kg} / \mathrm{m}^{2}\right)$ & $20.6 \pm 1.6$ \\
\hline 身体活動量（METs・h/W） & $18.7 \pm 12.3$ \\
\hline LDL-C $\quad(\mathrm{mg} / \mathrm{d} l)$ & $98 \pm 21$ \\
\hline $\mathrm{HDL}-\mathrm{C} \quad(\mathrm{mg} / \mathrm{d} l)$ & $67 \pm 14$ \\
\hline $\mathrm{HDL}_{2}-\mathrm{C} \quad(\mathrm{mg} / \mathrm{d} l)$ & $48.2 \pm 13.5$ \\
\hline $\mathrm{HDL}_{3}-\mathrm{C}(\mathrm{mg} / \mathrm{d} l)$ & $17.5 \pm 2.6$ \\
\hline Apo A-I $(\mathrm{mg} / \mathrm{d} l)$ & $150 \pm 23$ \\
\hline Apo B $(\mathrm{mg} / \mathrm{d} l)$ & $73 \pm 14$ \\
\hline $\mathrm{TG}(\mathrm{mg} / \mathrm{d} l)$ & $66 \pm 29$ \\
\hline $\mathrm{TC}(\mathrm{mg} / \mathrm{d} l)$ & $183 \pm 26$ \\
\hline LCAT $(\mathrm{nmol} / \mathrm{ml})$ & $74.6 \pm 14.2$ \\
\hline \multicolumn{2}{|l|}{ mean $\pm \mathrm{SD}$} \\
\hline \multicolumn{2}{|l|}{ BMI ; body mass index } \\
\hline \multicolumn{2}{|c|}{$\begin{array}{c}\text { METs } \cdot h / \mathrm{W} ; \text { metabolic equivalents } \cdot \text { hour/ } \\
\text { week }\end{array}$} \\
\hline \multicolumn{2}{|c|}{ LDL-C ; low density lipoprotein cholesterol } \\
\hline \multicolumn{2}{|c|}{ HDL-C; high density lipoprotein cholesterol } \\
\hline \multicolumn{2}{|c|}{ Apo ; apolipo protein } \\
\hline \multicolumn{2}{|l|}{ TG ; triglyceride } \\
\hline \multicolumn{2}{|l|}{ TC ; total cholesterol } \\
\hline \multicolumn{2}{|l|}{ LCAT; lecitin-cholest } \\
\hline
\end{tabular}

HEP Vol. 37, No. 2, 2010 
そこで $\mathrm{HDL}-\mathrm{C}$ と $\mathrm{HDL}_{2}-\mathrm{C}$ を従属変数とし, 緑黄 色野菜の摂取量と体重とを独立変数として重回帰分 析を行った結果, HDL-C および $\mathrm{HDL}_{2}-\mathrm{C}$ と緑黄色 野菜摂取量および体重との間には，それぞれ独立し た関係が認められた（表 3)。

緑黄色野菜を摂取量別に少ない (L 群), 中間（M 群), 多い（H 群）の 3 群に分けたところ, 年齢,

体重, BMI, METs・h/W に有意な差は認められな かったが, $\mathrm{L} ・ \mathrm{M}$ 群のカリウムは， $\mathrm{H}$ 群よりも有意 な低值を示した（表 4)。

表 2 栄養素等摂取量および食品群別摂取量

\begin{tabular}{|c|c|}
\hline & $(n=103)$ \\
\hline エネルギー (kcal) & $1,648 \pm 360$ \\
\hline たんぱく質（g） & $55.1 \pm 7.4$ \\
\hline 脂質 $(\mathrm{g})$ & $53.4 \pm 9.0$ \\
\hline 炭水化物（g） & $229.7 \pm 22.2$ \\
\hline カリウム $(\mathrm{mg})$ & $1,866 \pm 525$ \\
\hline レチノール当量（ $\mu \mathrm{g} ）$ & $445 \pm 324$ \\
\hline ビタミン C $(\mathrm{mg})$ & $85 \pm 59$ \\
\hline 食物繊維総量（g） & $11.2 \pm 8.0$ \\
\hline コレステロール（mg） & $266 \pm 101$ \\
\hline 飽和脂肪酸（g） & $16.29 \pm 3.79$ \\
\hline 一価不飽和脂肪酸（g） & $19.15 \pm 4.15$ \\
\hline 多価不飽和脂肪酸（g） & $10.32 \pm 2.53$ \\
\hline たんぱく質エネルギー比（\%) & $12.8 \pm 1.9$ \\
\hline 脂質エネルギー比（\%） & $29.5 \pm 4.8$ \\
\hline 糖質エネルギー比（\%） & $57.7 \pm 5.3$ \\
\hline 緑黄色野菜（g） & $74.1 \pm 55.0$ \\
\hline その他の野菜（g） & $94.0 \pm 58.8$ \\
\hline 総野菜（g） & $168.1 \pm 113.8$ \\
\hline 味増（g） & $5.1 \pm 4.0$ \\
\hline 豆類（g） & $28.4 \pm 31.2$ \\
\hline きのこ類（g） & $7.4 \pm 10.7$ \\
\hline 海藻類（g） & $5.4 \pm 9.4$ \\
\hline 油脂類（g） & $15.6 \pm 7.9$ \\
\hline 魚介類（g） & $36.4 \pm 24.8$ \\
\hline 肉類 $(\mathrm{g})$ & $60.0 \pm 31.6$ \\
\hline
\end{tabular}

mean $\pm \mathrm{SD}$
表 5 は, 共分散分析を用いて血清脂質の平均値か ら体重の影響を補正したものである。L群の HDL$\mathrm{C}$ は M 群と $\mathrm{H}$ 群のそれぞれに比較して有意な低值 を示した。 $\mathrm{HDL}_{2}-\mathrm{C}$ に有意な差は見られなかったも のの, $\mathrm{H}$ 群に比較して, L 群はボーダーラインであっ た $(p=0.081)$ 。

考察

HDL-C に影響を及ぼす因子として，飲酒，契煙， 肥満, 運動や身体活動, 年齢, 性, 栄養素等摂取量 などが報告されている8,9)。本研究における被検者 は，飲酒，喫煙の習慣を有さず，BMIも $25 \mathrm{~kg} / \mathrm{m}^{2}$ 以上の者はいない。また, 単相関分析を行った結果, $\mathrm{HDL}-\mathrm{C}$ と $\mathrm{HDL}_{2}-\mathrm{C}$ は METs・h/W と年齢とは有意 な関係を示さなかったため，これらの影響は少ない ものと推察される。若年女性の HDL-C は, エス卜 ロゲンの影響により，中年女性よりも高い傾向にあ ることが報告されている ${ }^{14)}$ 。本研究では, 月経周 期の 6 12 日目に採血を行うことにより，エストロ ゲンの影響をできるだけ同じ条件にした ${ }^{13)}$ 。

本研究における被検者の野菜摂取量は, 「平成 18 年国民健康・栄養調查」結果の，20 29 歳女性の 野菜摂取量平均值 $256.0 \mathrm{~g}$, 緑黄色野菜摂取量平均 值 $85.6 \mathrm{~g}$ と比較すると, それぞれ約 $90 \mathrm{~g}$ と約 $10 \mathrm{~g}$

表 3 重回帰分析

\begin{tabular}{lrrc} 
& & & $(n=103)$ \\
\hline & HDL-C & $\mathrm{HDL}_{2}-\mathrm{C}$ & Apo A-I \\
\hline 緑黄色野菜 & $0.249^{*}$ & $0.282^{* *}$ & $(-)$ \\
体重 & $-0.224^{*}$ & $-0.215^{*}$ & $-0.260^{* *}$ \\
\hline $\mathrm{R}^{2}$ & 0.110 & 0.124 & 0.067 \\
\hline \multicolumn{4}{c}{ HDL-C ; high density lipoprotein cholesterol } \\
Apo ; apolipo protein & \\
$* p<0.05, \quad * * p<0.01$ &
\end{tabular}

表 4 緑黄色野菜の摂取量別身体的特徵, 身体活動量, 栄養素等摂取量

\begin{tabular}{|c|c|c|c|}
\hline & $\begin{array}{c}\mathrm{L} \text { 群 }(n=34) \\
(26.9 \pm 22.6)\end{array}$ & $\begin{array}{c}\mathrm{M} \text { 群 }(n=35) \\
(58.1 \pm 21.3)\end{array}$ & $\begin{array}{r}\mathrm{H} \text { 群 }(n=34) \\
(137.0 \pm 53.5)\end{array}$ \\
\hline 年齢（歳） & $21 \pm 1$ & $21 \pm 1$ & $21 \pm 1$ \\
\hline 体重（kg） & $53.2 \pm 4.8$ & $52.0 \pm 5.5$ & $52.9 \pm 5.1$ \\
\hline BMI $\left(\mathrm{kg} / \mathrm{m}^{2}\right)$ & $21.0 \pm 1.5$ & $20.2 \pm 1.7$ & $20.8 \pm 1.6$ \\
\hline 身体活動量（METs · h/W） & $20.0 \pm 13.0$ & $16.2 \pm 11.5$ & $20.0 \pm 12.3$ \\
\hline エネルギー $(\mathrm{kcal})$ & $1,690 \pm 390$ & $1,577 \pm 290$ & $1,678 \pm 391$ \\
\hline カリウム（mg） & $1,642 \pm 535^{*}$ & $1,826 \pm 307^{*}$ & $2,130 \pm 586$ \\
\hline \multicolumn{4}{|l|}{ mean $\pm \mathrm{SD}$} \\
\hline \multicolumn{4}{|c|}{ BMI ; body mass index } \\
\hline \multicolumn{4}{|c|}{ METs $\cdot h / \mathrm{W}$; metabolic equivalents $\cdot$ hour/week } \\
\hline
\end{tabular}


表 5 緑黄色野菜摂取量別血液生化学検查值

\begin{tabular}{|c|c|c|c|}
\hline & $\begin{array}{r}\mathrm{L} \text { 群 } \quad(n=34) \\
(26.9 \pm 22.6)\end{array}$ & $\begin{array}{c}\mathrm{M} \text { 群 } \quad(n=35) \\
(58.1 \pm 21.3)\end{array}$ & $\begin{array}{c}\mathrm{H} \text { 群 }(n=34) \\
(137.0 \pm 53.5) *\end{array}$ \\
\hline LDL-C $\quad(\mathrm{mg} / \mathrm{d} l)$ & $98 \pm 4$ & $97 \pm 4$ & $97 \pm 4$ \\
\hline HDL-C $(\mathrm{mg} / \mathrm{d} l)$ & $62.0 \pm 2.2^{* \dagger}$ & $69.2 \pm 2.2$ & $68.8 \pm 2.2$ \\
\hline $\mathrm{HDL}_{2}-\mathrm{C} \quad(\mathrm{mg} / \mathrm{d} l)$ & $44.8 \pm 2.3$ & $49.2 \pm 2.2$ & $50.5 \pm 2.3$ \\
\hline $\mathrm{HDL}_{3}-\mathrm{C} \quad(\mathrm{mg} / \mathrm{d} l)$ & $17.8 \pm 0.5$ & $17.4 \pm 0.4$ & $17.3 \pm 0.5$ \\
\hline Apo A-I $(\mathrm{mg} / \mathrm{d} l)$ & $142 \pm 4$ & $156 \pm 4$ & $151 \pm 4$ \\
\hline Apo B (mg/d $l)$ & $72 \pm 2$ & $73 \pm 2$ & $73 \pm 2$ \\
\hline $\mathrm{TG}(\mathrm{mg} / \mathrm{d} l)$ & $63 \pm 5$ & $70 \pm 5$ & $64 \pm 5$ \\
\hline $\mathrm{TC}(\mathrm{mg} / \mathrm{d} l)$ & $178 \pm 5$ & $189 \pm 4$ & $182 \pm 5$ \\
\hline $\operatorname{LCAT}(\mathrm{nmol} / \mathrm{ml})$ & $74.4 \pm 2.5$ & $76.7 \pm 2.4$ & $72.5 \pm 2.5$ \\
\hline $\begin{array}{l}\text { 共変量 : 体重 } \\
\text { LDL-C ; low dens } \\
\text { HDL-C ; high den } \\
\text { Apo ; apolipo prot } \\
\text { TG ; triglyceride } \\
\text { TC ; total choleste } \\
\text { LCAT ; lecitin-cho } \\
{ }^{*} p<0.05 \text {; vs. M } \\
{ }^{\dagger} p<0.05 \text {; vs. H 君 } \\
\text { *緑黄色野菜の摂 } \\
\text { 血液生化学検査 }\end{array}$ & $\begin{array}{l}\text { ol } \\
\text { esterol acyltrans } \\
\text { 又量は平均值 } \pm \\
\text { は平均值 } \pm \text { 標 }\end{array}$ & $\begin{array}{l}\text { lesterol } \\
\text { holesterol }\end{array}$ & \\
\hline
\end{tabular}

少ない結果となった ${ }^{5)}$ 。しかし，その他の栄養素等 はほぼ満たしていた ${ }^{15)}$ 。

被検者を緑黄色野菜摂取量別に $\mathrm{L} \cdot \mathrm{M} \cdot \mathrm{H}$ 群の 3 群に分けたところ, $\mathrm{L} \cdot \mathrm{M}$ 群は $\mathrm{H}$ 群に比較して, 力 リウムにおいて有意な低值を示した。しかしカリウ ムは緑黄色野菜に多く含まれ，また HDL-C と $\mathrm{HDL}_{2}-\mathrm{C}$ と有意な関係を示さなかったため, カリウ ムを補正することはせず， HDL-C と $\mathrm{HDL}_{2}-\mathrm{C}$ と有 意な関係を示した体重のみを補正した。その結果, 健康な女子大学生において, 緑黄色野菜摂取量は HDL-C と $\mathrm{HDL}_{2}-\mathrm{C}$ とともに関連があり，緑黄色野 菜摂取量が少ない L 群の HDL-C は緑黄色野菜摂取 量が多い $\mathrm{M}$ 群と $\mathrm{H}$ 群よりも有意な低值を示すこと が示唆された。しかし，M 群の HDL-C は H 群よ りも有意な低值を示さなかった。これらの結果から すると，L群のようにかなり緑黄色野菜の摂取が少 なくない限り, 緑黄色野菜の摂取量は HDL-C に影 響しないといえるのかもしれない。しかし，この点 については今後緑黄色野菜の摂取量がより多い症例 数を増やすなどの検討が必要と思われる。

HDL-C は抹消組織や細胞から余剩なコレステ ロールを回収して肝臓へ運ぶ「コレステロール逆転 送」により，血中コレステロールの低下作用や動脈 硬化の発現抑制作用が期待されると考えられてい る ${ }^{16)}$ HDLはコレステロール逆転送に招いて，
$\mathrm{HDL}_{2}$ となってコレステロールを肝蔵へ運ぶ $\left.{ }^{9}\right)$ 。本 研究においては, H 群に比較して L 群の $\mathrm{HDL}_{2}-\mathrm{C}$ は 有意な低值を示さなかったものの, ボーダーライン であったことから $(p=0.081)$, 今後, 緑黄色野菜 の摂取量と $\mathrm{HDL}_{2} \mathrm{C}$ との関係についても症例数を増 やして検討する必要があると思われた。

本研究において緑黄色野菜摂取量は HDL-C と $\mathrm{HDL}_{2}-\mathrm{C}$ とともに関連があり, 緑黄色野菜摂取量が 少ない $\mathrm{L}$ 群の HDL-C は M 群と $\mathrm{H}$ 群よりも有意な 低值を示すことが示唆されたが, HDL-C の平均值 は 3 群ともに基準值の範囲内であった。しかし, HDL-C は基準值内でも，HDL-C が低いほど冠動脈 疾患の発症率が高く, HDL-C が高いほど発症率が

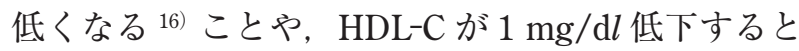
虚血性心疾患の発症は 2 3\% 増加すると報告され ている ${ }^{16)}$ ことを考慮すると, 本研究で得られた結 果は一次予防という観点からみて，意義あるものと 思われる。

昭和 30 年代後半の高度成長期以降， 日本人の食 生活は米中心から多様化し，畜産物などの消費が増 加して脂質の過剩摂取状態になり, 生活習慣病が増 加した。主な生活習慣病として, 癌, 高血圧症, 糖 尿病, 脂質異常症, 肥満症が挙げられるが, これら の多くは動脈硬化発症の代表的な危険因子であり， これらがいくつも集積して動脈硬化の進行を促進し, 
虚血性心臟病や脳血管障害の原因となっている ${ }^{17) 。 ~}$ 生活習慣病の観点から，中高年者を対象とした研 究が多い中 ${ }^{3)}$, 若い女性でも緑黄色野菜摂取量は $\mathrm{HDL}-\mathrm{C}$ と $\mathrm{HDL}_{2}-\mathrm{C}$ とともに関連があることが示唆 された。通常でも動脈硬化は青年期から徐々に進行 しており, 中年期以降, 脂質異常症になると, その 進行は急速に早まり, 動脈硬化が引き起こす合併症 の危険性は増大する ${ }^{14)}$ 。そのため早い段階から食 習慣の是正が必要であると思われる。したがって, 幼少期から将来の健康の重要性を認識し, 食を選ぶ 知識や正しい食習慣を身につける食育は重要にな る。日本人の緑黄色野菜摂取量を上げるために具体 的な食事指導を行う必要があると思われた。

今回の研究では, 緑黄色野菜の摂取不足が HDLCの低下を招く機序は解明できていない。我々は日 常の食事において, サラダや煮物など単一成分とし てではなく, 食物として複合的に種々の野菜を同時 に摂取している。そのため, 体内で野菜の持つ複数 の栄養成分の効果が拮抗あるいは相乗効果を発揮し て存在する場合も考えられる。その他の野菜では HDL-C との関連が見られなかったことについても, 今後症例数を増やすなどして検討する必要がある。 しかしながら, 健康な女子大学生において, 緑黄色 野菜摂取量は $\mathrm{HDL}-\mathrm{C}$ と $\mathrm{HDL}_{2} \mathrm{C}$ とともに関連があ り, 脂質代謝において, 緑黄色野菜の摂取が動脈硬 化などの予防や改善に寄与する可能性を示唆するも のとなった。

\section{参考文献}

1) World Cancer Research Fund and American Institute for Cancer Research : Food, Nutrition and the Prevention of Cancer : A Global Perspective, 436-446, 1997

2) Lampe JW : Health Effects of Vegetables and Fruits :
Assessing Mechanisms of Action in Human Experimental Studies, Am. J. Clin. Nutr. 70 (suppl）: 473S-490S, 1999

3）池上幸江, 梅垣敬三, 篠塚和正, 江頭祐嘉合 : 野菜と野菜 成分の疾病予防及び生理機能への関与. 栄養学雑誌 61 : 275-288, 2003

4）健康 - 栄養情報研究会編 : 国民健康 - 栄養の現状一平成 17 年厚生労働省国民健康・栄養調査報告より一, 第一出 版, 東京, 付録 5, 26-27, 2008

5) 厚生労働省健康局総務課生活習慣病対策室編: 平成 18 年国民健康・栄養調査結果の概要, 24-25, 2008

6）木下誠：動脈硬化性疾患予防ガイドライン 2007 年版の ポイント一脂質異常症を中心に一, 食生活 $101: 16-23$, 2007

7）松沢佑次, 山下静也 : コレステロールの代謝回転におけ るHDL の役割とその異常, 医歯薬出版株式会社, 東京, 112-121, 1987

8) 奥田奈賀子, 上島弘嗣 : 日本人と脂質異常症の疫学 コ レステロール, 臨床栄養 $113: 411-416,2008$

9) 武富保: コレステロールの合成, 輸送, そして排泄, ハー パー生化学 原書, 25 版 : 308-321, 2005

10）寺本民生 : 動脈硬化性疾患予防ガイドライン 2007 年版, 臨床栄養 $113:$ 473-478, 2008

11) Ainsworth BE, Haskell WL, Leon AS, et al. : Compendium of Physical Activities : Classification of Energy Cost of Human Physical Activities, Med. Sci. Sports Exerc. 25 : 71-80, 1993

12) Ainsworth BE, Haskell WL, Whitt MC, et al. : Compendium of Physical Activities : An Update of Activity Codes and MET Intensities, Med. Sci. Sports Exerc. 32 : s498-s516, 2000

13) Philippa MLW, Naswrin C, Enske AG, A. Stewart T : Increase of High-density Lipoprotein Cholesterol at Ovulation in Healthy Women, Atherosclerosis 105 : 171-178, 1994

14）和田洋一郎: 高脂血症, 新版 病気の地図帳, 講談社, 東 京, 157, 2006

15）第一出版編集部編: 厚生労働省策定 日本人の食事摂取 基準 (2005 年版), 第一出版, 東京, 2005

16）山下静也 : アポ蛋白 A-I, ABCA1 および脂質転送蛋白の 視点から, 臨床栄養 $113: 435-443,2008$

17）渡辺照男：疾病の概要 個人差と個人の反応 生活習慣 病, カラーで学べる病理学, 第 2 版, ヌーヴェルヒロカ ワ; 6,2005 


\section{Relationship between Green and Yellow Vegetable Intakes and High-Density Lipoprotein Cholesterol in Collegiate Women}

Yoshie Murakami, Reina Kishida, Reika Oshikata, Yuka Noda, Atsumi Nagata, Noriko Mivamoto, Youko Terazawa, Hiroyuki Imamura

The purpose of this study was to investigate the relationship between green and yellow vegetable intakes and high-density lipoprotein cholesterol (HDL-C). Subjects were 103 collegiate women, who neither drank nor smoked. The results of the multiple regression analysis showed that $\mathrm{HDL}-\mathrm{C}$ and $\mathrm{HDL}_{2}-\mathrm{C}$ were significantly related with green and yellow vegetable intakes and body weight. When subjects were subdivided into 3 groups according to green and yellow vegetable intakes, the lowest category showed significantly lower HDL-C than the highest and middle categories after adjusting for body weight in the analysis of covariance. These results indicate that green and yellow vegetable intakes are related with $\mathrm{HDL}-\mathrm{C}$ and $\mathrm{HDL}_{2}-\mathrm{C}$, and $\mathrm{HDL}-\mathrm{C}$ decreases with decreasing green and yellow vegetable intakes.

Key Words : High-density Lipoprotein Cholesterol, Green and Yellow Vegetable Intakes, Lifestyle-related Disease, Collegiate Women 